\section{Brain, Behavior and Evolution}

Ashwell, K.W.S. 69, 85, 203

Austad, S.N. 39

Bentley, G. 123

Canfield, J.G. 188

Coddington, E.J. 135

de Kort, S.R. 1

Fenton, M.B. 165

González, A. 150

Grunwald, W. 177

Hau, M. 123

Hollis, D.M. 135

Hurd, P.L. 53

Iwaniuk, A.N. 53

Kristan, D.M. 39
Laberge, F. 177

Laverghetta, A.V. 10

López, J.M. 150

Lutterschmidt, W.I. 103

Moore, F.L. 135

Moreno, N. 150

Morona, R. 150

Mühlenbrock-Lenter, S. 177

Ohmori, Y. 111

Onuki, A. 111

Perfito, N. 123

Phillips, M. 203

Pravosudov, V.V. 1

Ratcliffe, J.M. 165
Reiner, A. 10

Roth, E.D. 103

Roth, G. 177

Shettleworth, S.J. 165

Shupe, J.M. 39

Somiya, H. 111

Stenkamp, D.L. 39

Toledo, C.A.B. 10

Veenman, C.L. 10

Wang, H. 10

Wilson, D.A. 103

Wylie, D.R.W. 53

Yamamoto, K. 10

\title{
Subject Index Vol. 67, 2006
}

Agkistrodon piscivorus 103

Amniotes 177

Amphibian(s) 135, 150, 177

Amygdala 177

Apodiformes 53

Birds 123

Brain 1

Calbindin 69, 85, 203

Calretinin 69, 85, 203

Caprimulgiformes 53

CB1 135

Cerebellum 53

Comparative method 165

- neuroanatomy 150, 177

Corvids 1

C-start 188

Development 177

Diencephalon 10

Domestication 39

Dorsal cortex 103

Echidna 69, 85, 203

Echolocation 165

Escape 188

Evolution 39, 53, 150, 177

Eye 39

Fish 188
FMRFamide peptides 150

Food-caching 1

Foraging behavior 165

Ganglion cell 39

Glutamate 10

- receptors 10

GnRH 123

Habitat complexity 165

Hippocampus 1

Immunohistochemistry 150

In situ hybridization 135

Innervation pattern 111

LH 123

Limbic system 177

Mammal 39

Mauthner cell 188

Medial cortex 103

Microchiroptera 165

Mouse 39

Neurofilament protein 69,85

Neuropeptide FF 150

Nightjar 53

Occipital nerve 111

Owl 53

Parvalbumin 69, 85, 203

Photoreceptor 39
Pigeon 10

Platypus 69, 85, 203

Red piranha 111

Reproductive timing 123

Reptiles 103

Rough-skinned newt 135

Sex differences 103

Snakes 103

Sonic motor neuron 111

- - nucleus 111

- muscle 111

Spatial ecology 103

- memory 1

Spinal nerve 111

Startle response 188

Strigiformes 53

Taeniopygia guttata 123

Taricha granulosa 135

Telencephalon 10, 103, 177

Testis volume 123

Vision 39,188

Visuospatial coding 188

Vocalizing fish 111

Water restriction 123

Zebra finch 123 